\title{
Three new species and a new genus of subterranean Zuphiini from the Pilbara region of north-western Australia (Coleoptera: Carabidae: Harpalinae)
}

\author{
Martin Baehr \\ Zoologische Staatssammlung, Münchhausenstr. 21, D-81247 München, Germany. \\ Email: martin.baehr@zsm.mwn.de
}

\begin{abstract}
Three new carabid species of the zuphiine genera Parazuphium Jeannel, subgenus Austrozuphium Baehr, and Typhlozuphium gen. nov. are described from the Pilbara in north-western Australia: Parazuphium pilbarae sp. nov. Typhlozuphium humicolum sp. nov. and T. longipenne sp. nov. The new species were detected in the course of a survey for subterranean insects in mining areas and were collected by 'trog scrape'. All three species are depigmented and possess very elongate antennae, character states that subterranean or cavicolous carabid species tend to develop) Parazuphium pilbarae has small eyes and is probably related to Parazuphium (Austrozuphium) flavescens Baehr from the Kimberleys. Both Typhlozuphium species are blind and are further characterised by very long legs, elongate, posteriad barely widened head, and very elongate, parallel-sided elytra which lack the sinuate apex that is characteristic for species of the subgenus Austrozuphium.
\end{abstract}

KEYWORDS: taxonomy, new genus, new species, Western Australia, Carabidae, Zuphiini, Parazuphium, Typhlozuphium

\section{INTRODUCTION}

Zuphiini is a moderately large tribe of quite variously shaped carabid beetles which are characterised by their depressed body, wide head with a remarkably narrow 'neck', and usually very elongate scapus of the antenna. The limits of Zuphiini as well as their subdivision into subtribes are still controversially discussed; in particular the relationships of the subtribe (or tribe) Planetina (-ini) are unresolved (see Habu 1967, Lorenz 2005, Bouchard et al. 2011). In Australia the subtribes Leleupidiina, Dicrodontina, Zuphiina, and Planetina occur, according to the subtribal classification of Lorenz (2005).

Zuphiini occur in all zoogeographical regions, but are most common in tropical and subtropical areas. The Australian Zuphiines were revised by Baehr (1984, 1985a, 1985b, 1986a, 1986b, 1988), but since these papers, several additional species have been described by Baehr (1992, 1995, 2001, 2008a, 2008b, 2010, 2012) and Moore (1995). Presently, eight genera including 51 species and subspecies are recorded from Australia. Most species occur in the tropical belt across northern Australia.

Rather little is known about life histories and habits of Zuphiini, including the Australian species, but the tribe is renowned for the edaphic life of all species, with great numbers of species living either in leaf litter of rain forests, in soil, or in caves. Most presently known Australian species are large-eyed and darkly coloured. They are typically strictly nocturnal species that live under cover on the ground and they are normally only detected at light. The two known species of the genera Speothalpius and Speozuphium described by Moore (1995) are blind, depigmented, cavicolous beetles found in the Nullarbor Plain. Some other species of Parazuphium Jeannel, of the subgenus Austrozuphium Baehr, are more or less depigmented and possess smaller eyes and longer antennae than most known zuphiines, e.g. P. flavescens Baehr, 1985 from far north-western Australia (Baehr 1985). The single Australian species of the subtribe Leleupidiina, Colasidia monteithi Baehr, 1988, is a small, depigmented, small-eyed species that was found in leaf litter in a North Queensland rain forest (Baehr 1988). The subtribe Dicrodontina includes 12 species of the phylogenetically plesiotypic genus Acrogenys Macleay, 1864 which exclusively occur in northern Australia from north-eastern Queensland to the Pilbara in northern Western Australia.

The new genus and three new species described in the present paper belong to the subtribe Zuphiina which in 
Australia includes the genera Pseudaptinus Castelnau, 1834, Zuphium (s. str.) Latreille, 1806, Parazuphium Jeannel, 1942, and probably also Speozuphium Moore. 1995 and Speothalpius Moore. 1995.

By courtesy of Nadine Guthrie, Brian Hanich, and Nikolai Tatarnic (Perth) I received a small sample of carabid beetles for identification. The specimens were collected during a survey of mining areas in the Pilbara, north-western Western Australia. All specimens were sampled by 'trog scrape'. This is a method of sampling troglobiotic animals from drill bores in the ground in iron ore mining areas as described by Halse and Pearson (2014). As a consequence, the sample consists of depigmented specimens with small eyes or without visible eyes. Included in the sample are specimens from the tribes Physocrotaphini, Zuphiini, and Bembidiini, subtribe Anillina. Both Zuphiini and Anillina are known to have several soil or cave inhabiting species.

In this paper three new species and a new genus of Zuphiini are described.

\section{METHODS}

In this taxonomic survey standard methods were used. Genitalia were removed from specimens and relaxed overnight in a jar under moist atmosphere. They were then cleared for a short while in a hot bath of $10 \% \mathrm{KOH}$. Specimens were very fragile due to being preserved in $100 \%$ ethanol so only a single pinned specimen was photographed. For better presentation of essential characters the habitus of the head and pronotum is illustrated. The habitus photograph was obtained with a digital camera using ProgRes CapturePro 2.6 and AutoMontage, and was edited with Corel Photo Paint $\mathrm{X} 4$.

Measurements were taken using a stereo microscope with an ocular micrometer. Body length was measured from apex of labrum to apex of elytra. Length of pronotum was measured in a straight line from the apex of the anterior angles to the most produced part of the base. Length of the elytra was measured from the most advanced part of the humerus to the very apex.

The types of the new species are stored in Western Australian Museum, Perth (WAM), except one paratype which is stored in the working collection of the author at Zoologische Staatssammlung München (CBM).

\section{COLLECTING METHOD}

During a survey carried out in iron ore mining areas in the Pilbara, north-western Australia (Halse and Pearson 2014) describe extensively, their method of sampling subterranean fauna. The collectors used nets which were sunken into drill bores in the ground and then lifted out again, at which the margins of the bores were scraped by the net and arthropods living in the earth were brought to the surface. For the carabid species worked in the present paper this was done in depths of up to $60 \mathrm{~m}$ below surface level. According to the authors this collecting method in general was more successful than sampling animals in the drill bores using pitfall traps.

\section{TAXONOMY}

\section{Family Carabidae Latreille, 1802}

Subfamily Harpalinae Bonelli, 1810

Tribe Zuphiini Bonelli, 1810

Subtribe Zuphiina Bonelli, 1810

\section{REMARKS}

In this paper, a new species of the genus Parazuphium Jeannel, subgenus Austrozuhpium Baehr, 1985 and two species of the new genus Typhlozuphium are described from the Pilbara Region. From this area one species each of Parazuphium s. str. and of the subgenus Austrozuphium have been recorded, in addition to single species of the genera Acrogenys Macleay, Pseudaptinus Castelnau, Zuphium Latreille, and Planetes Macleay.

\section{Genus Parazuphium Jeannel, 1942}

Parazuphium Jeannel 1942: 1095; Baehr 1985b: 298; Baehr 2001: 85; Lorenz 2005: 506.

\section{TYPE SPECIES}

Zuphium chevrolati Castelnau, 1833, by original designation.

\section{DIAGNOSIS}

Genus of subtribe Zuphiina. Rather small, depressed, usually yellow to brown species; eyes present, moderately sized to rather small: antenna elongate with elongate scapus; $1^{\text {st }}$ antennomere more than $1.5 \mathrm{x}$ as long as $2^{\text {nd }}$ and $3^{\text {rd }}$ antennomeres together, with several erect setae; elytral striae indistinct; aedeagus short and compact; gonocoxite 2 falciform, asetose.

\section{REMARKS}

The genus is widely distributed in the Palearctic, Afrotropical, Oriental, and Papuan-Australian Regions (Lorenz 2005).

\section{Parazuphium (Austrozuphium) Baehr, 1985}

Austrozuphium Baehr 1985: 307; Lorenz 2005: 507.

\section{TYPE SPECIES}

Zuphium mastersii Castelnau, 1867, by original designation.

\section{DIAGNOSIS}

As for genus; head with a single seta behind the eye; elytral striae very feeble; apex of elytra distinctly 
sinuate and moderately incurved towards suture; aedeagus compact and usually heavily sclerotised, with very short orificium and with two short, sclerotised plates in the opening.

\section{REMARKS}

This subgenus is exclusively Australian (Baehr 1985). Presently five species are known which occur from eastern South Australia through the whole of eastern Australia, the northern parts of Northern Territory, to the Pilbara in north-western Western Australia.

\section{Parazuphium (Austrozuphium) pilbarae sp. nov.}

Figures 1, 4

http://www.zoobank.org/urn:Isid:zoobank. org:act:A14C1137-72FC-4694-9E0B-89AEF70D9225

\section{MATERIAL EXAMINED}

\section{Holotype}

Australia: Western Australia: , 'W.A.: Flinders Mine, c. $73 \mathrm{~km}$ NNW. Tom Price 22 08'14.60"S 117²5'28.60"E (WGS 84) 07 Feb. 2012 J.S. Cocking, G.B. Pearson (HPRC0930) Trog scrape, 17 m' (WAM E88463).

\section{DIAGNOSIS}

Yellow, depressed species with elongate, somewhat cordiform pronotum and small eyes; distinguished from the very similar $P$. flavescens Baehr, 1985 from the Kimberleys by smaller, laterad virtually not produced eye, slightly longer median antennomeres, slightly laterad produced basal angle of pronotum, and shortened metathoracic wings.

\section{DESCRIPTION}

Measurements: Length: $3.5 \mathrm{~mm}$; width: $1.25 \mathrm{~mm}$. Ratio width/length of pronotum: 1.24; ratio width of widest diameter/width of baser of pronotum: 1.86; ratio width of head/width of pronotum: 0.96; ratio length/ width of elytra: 1.53; ratio length/width of scapus: 6.6; ratio length/width of $6^{\text {th }}$ antennomere: 4.0.

Colour: Upper and lower surfaces dirty yellow, palpi, antenna, and legs even slightly paler.

Head (Figure 1): Almost as wide as pronotum, relatively short and wide, wide between eyes. Upper surface gently convex. Eye very small, laterad virtually not protruded. Frons with a very small, inconspicuous, impression on either side just behind the clypeal suture. Neck very narrow, separated by a deep, convex furrow. Clypeus bisetose, setae elongate. Labrum slightly concave at apex, 6-setose. Mandibles short and wide, scrobe with some fairly elongate setae. Palpi narrow and elongate, slightly widened apicad, rather densely pilose, in particular the basal palpomere of the maxillary palpus rather hirsute. Antenna very elongate, scapus elongate,

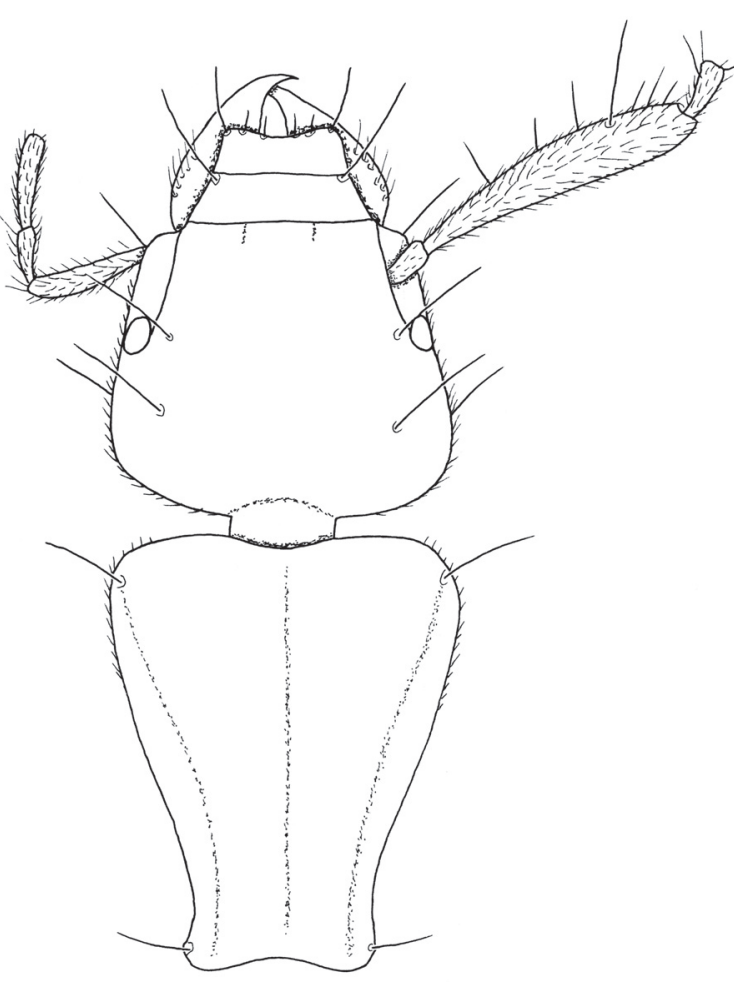

FIGURE 1 Head and pronotum: 1, Parazuphium pilbarae sp. nov. Scale bars $=1 \mathrm{~mm}$.

about as long as diameter of head, with several elongate setae, densely pilose; median antennomeres $>4 \mathrm{x}$ as long as wide. Posterior supraorbital seta far removed from posterior margin of eye. Surface of head sparsely, though rather coarsely punctate and pilose, pilosity very short and inclined anteriad. Microreticulation fine and superficial, about isodiametric.

Prothorax (Figure 1): Narrow and elongate, much longer than wide, cordiform, widest close to apex. Apex wide, straight, apical angles rounded, shortly pilose. Lateral margin in apical two thirds oblique and gently convex, in basal third straight and slightly concave. Basal angles slightly triangularly produced, situated slightly in front of base. Base narrow, almost straight. Lateral marginal explanation very shallow, inconspicuous. Both, apex and base not margined. Disk rather depressed. Median line very fine, slightly impressed, almost attaining apex and base. No transverse sulci visible. Basal grooves shallow, narrow. Anterior marginal seta situated shortly behind apical angle, posterior seta situated on the basal angle. Surface with moderately dense, fairly coarse, but very shallow punctures, and with dense, short, slightly declined pilosity. Microreticulation extremely fine and superficial, composed of more or less isodiametric meshes. 
Elytra: Fairly elongate and but slightly widened apicad; dorsal surface depressed. Humerus obliqueconvex. Lateral margins straight and very slightly oblique. Apex distinctly sinuate, slightly oblique, markedly incurved towards suture; external apical angles widely rounded. At least the internal striae just perceptible though barely impressed, internal intervals in basal half very slightly raised. Surface with dense and slightly rugose punctures in 2-3 rows. Pilosity fairly dense but very short, depressed. Microreticulation distinct, slightly transverse. Marginal setae very elongate. Metathoracic wings slightly shortened.

Ventral surface: Densely punctate and pubescent. Metepisternum rather wide, c. $1.5 \mathrm{x}$ as long as wide at apex. Terminal sternite in male with one elongate seta on either side.

Legs: Narrow and elongate, densely pilose. Tarsi pilose on upper and lower surfaces. $4^{\text {th }}$ tarsomeres widened and deeply cleft. Three basal tarsomeres of the male protarsus sparsely, biseriately pilose.

Male genitalia (Figure 4): Genital ring strongly sclerotised, wide, almost quadrangular, with wide base and apex. Aedeagus very short and compact, very heavily sclerotised, markedly curved as well in vertical as horizontal directions. Apex short and rather wide, obtusely triangular. Orificium short, situated on the left side, dorsally on either side with a short, sclerotised plate. Internal sac with some extremely heavily sclerotised folds some of which are slightly denticulate; parameres small, very dissimilar.

Female gonocoxites: Unknown.

Variation: Unknown.

\section{DISTRIBUTION}

This species is known only from the type locality in the Pilbara region of north-western Western Australia.

\section{REMARKS}

The holotype was sampled by 'trog scrape' as discussed above under 'Collecting method', at $17 \mathrm{~m}$ below the surface.

According to the body shape and structure this species is most similar to P. flavescens Baehr, 1985, from the Kimberley region of north-western Australia. Unfortunately, of that rare species so far only females have been recorded, therefore the putative relationship cannot be corroborated by comparison of the male genitalia.

\section{ETYMOLOGY}

The name refers to the region where the species was detected, the Pilbara in north-western Australia south of Great Sandy Desert.

\section{Genus Typhlozuphium gen. nov.}

\author{
http://www.zoobank.org/urn:Isid:zoobank. \\ org:act:8F994D45-545D-43F2-B8C3-64851A439507
}

\section{TYPE SPECIES}

Typhlozuphium humicolum sp. nov.

\section{DIAGNOSIS}

A genus of the subtribe Zuphiina; characterised by narrow and elongate, posteriad barely widened but widely rounded head, lacking eyes, deeply excised labrum, very small, anteriorly convex clypeus which bears a third, median seta, presence of a single 'supraorbital' seta, cordiform, asetose prothorax with laterally well visible proepisternum, narrow and elongate, almost parallel-sided, dorsally rather convex elytra with oblique, not sinuate nor incurved apex, very elongate legs, comparatively elongate aedeagus with wide apex and elongate, sclerotised rods at the top of the internal sac, falciform, asetose gonocoxite 2, and remarkably elongate setae at the upper ventral rim of gonocoxite 1 .

\section{DESCRIPTION}

Colour: Upper and lower surfaces, palpi, antenna, and legs pale yellow.

Head: Elongate, slightly wider than pronotum, posteriad little widened, about elliptical, widely rounded towards neck. Eye absent. Neck short, narrow, separated by a deep furrow. Clypeus small, apical margin convex, trisetose, i.e. with a slightly shorter seta in middle, lateral setae elongate. Labrum deeply concave at apex, 6-setose, the lateral seta longer than the median ones. Mandibles comparatively elongate, wide, at apex suddenly incurved, lateral margin near base with several elongate setae. Palpi narrow and elongate, apical palpomeres slightly widened apicad, palpi densely pilose; the basal palpomere of the maxillary palpus hirsute, the basal palpomere of the labial palpus at apex with several elongate setae. Mentum with a quadrate tooth, 4-setose behind the tooth. Labium short, glossa wide at apex, paraglossae apparently fused to glossa, at apex 5-setose. Lacinia elongate, median margin with many elongate, stout setae. Galea narrow and elongate, impilose. Antenna very elongate, scapus longer than diameter of head, with one elongate seta near apex and several very short, erect setae within the fairly dense, depressed pilosity; median antennomeres with very dense, adpressed, very short pilosity. One supraorbital seta present, situated at apical third of head. Surface of head sparsely punctate and pilose, pilosity on surface short and inclined anteriad, laterally longer. Microreticulation fine and superficial, about isodiametric.

Prothorax: Rather narrow and elongate, much longer than wide, cordiform, widest at or slightly in front of middle. Apex in middle straight, laterally markedly oblique; apical angles obtusely rounded. Lateral margin 
in basal half concave, near base straight. Basal angles slightly removed from base, very slightly triangularly produced. Base rather narrow, in middle slightly concave. Lateral margin slightly carinate, marginal explanation in apical half narrow and shallow, in basal half slightly wider and deeper. Both, apex and base not margined. Disk depressed but uneven, in apical half slightly convex, in basal half slightly impressed. Median line fine, inconspicuous, almost attaining apex and base. Basal grooves shallow, rather elongate. In middle of pronotum proepisternum well visible from above, wide and convex, producing the widest diameter of pronotum. No marginal setae or punctures visible. Surface with dense, coarse, transverse furrows, interrupted by rather dense punctures, with fairly dense, short, declined pilosity. Microreticulation extremely fine and superficial, composed of more or less isodiametric meshes.

Elytra: Elongate and parallel-sided or almost so; dorsal surface convex but depressed on disk. Humerus oblique. Lateral margins straight. Apex very oblique, not sinuate, not incurved at suture, narrowly marginate; external apical angles widely rounded. At least two median striae just perceptible though barely impressedNo discal punctures and setae visible. Lateral marginal setae extremely elongate, composed of two groups: 4 setae behind humerus, 2 setae near external apical angle. Surface with dense and rasp-like punctation. Pilosity dense, fairly elongate, declined posteriad. Microreticulation distinct, isodiametric. Surface rather dull. Metathoracic wings completely reduced.

Lower surface: Moderately densely punctate and pilose. Pilosity rather elongate, on head and prothorax inclined anteriad, on abdomen inclined posteriad. Metepisternum short, little longer than wide at apex. $1^{\text {st }}$ visible abdominal sternite very elongate, almost as long behind metacoxa as the three following sternites. Terminal sternite in both sexes with one elongate seta on either side.

Legs: Very narrow and elongate, densely pilose. Metacoxa $>5 \mathrm{x}$ as long as wide. Tarsi densely pilose on upper and lower surfaces. $4^{\text {th }}$ tarsomeres widened and deeply cleft, densely pilose on lower surface. Tarsal claws very small. Male protarsus not widened and squamose on lower surface, similar to that of female.

Male genitalia: Genital ring fairly narrow, slightly asymmetric, with wide base and rounded apex. Aedeagus rather elongate, straight, little widened in middle, with slightly convex lower surface. Apex depressed, at tip widely more or less rounded. Orificium elongate, situated in middle of upper surface, dorsally on either side with a narrow, elongate rod. Internal sac with some folds and one or two narrow, curved sclerites at bottom in middle of the left side. Parameres moderately large, very dissimilar, right one short, both asetose.

Female gonocoxites): Gonocoxite 1 elongate, with c. 6 extremely elongate setae at the upper ventral rim. Gonocoxite 2 falciform, without any setae. Also the lateral plate at its upper median rim with one or two extremely elongate setae.

\section{REMARKS}

The body shape and, in particular, the presence of additional erect setae on the scapus of the antenna suggest a fairly close relationship of Typhlozuphium with the genus Parazuphium, particularly to the depigmented, small-eyed species of the subgenus Austrozuphium. Several character states of the external morphology, e.g. shape and setosity of the clypeus, shape of the labrum, total loss of the eyes, shape of the prothorax, loss of the marginal prothoracic setae, shape of the apex of the elytra, etc., however, demonstrate that it is a well separated genus that in many respects is apomorphic as compared with Parazuphium. The aedeagus, however, in its shape and structure, seems to be plesiomorphic, at least when compared with the recorded aedeagi of the species of Austrozuphium. Therefore, Typhlozuphium could be well related to Parazuphium, but may have separated from the Parazuphium stock very basally.

\section{ETYMOLOGY}

The name refers to the total absence of eyes. The generic name is considered to be neuter.

\section{Typhlozuphium humicolum sp. nov.}

Figures 2, 5, 7

http://www.zoobank.org/urn:Isid:zoobank. org:act:CA6D4BC1-386C-45C3-80CD-78EA5F94DD25

\section{MATERIAL EXAMINED}

\section{Holotype}

Australia: Western Australia: , 'W.A.: Mining Area C, c. 93 km NW. Newman 2254'08.90"S 118 58'53.10"E (WGS 84) 09 Apr. 2010 M.K.Curran, J.S.Cocking (PSD0181R) Trog scrape, 49 m' (WAM E88564).

\section{Paratypes}

Australia: Western Australia: 1 , 'W.A.: Mining Area C, c. $95 \mathrm{~km} \mathrm{NW}$. Newman 22 53'55.80"S $118^{\circ} 57^{\prime} 57.40^{\prime \prime} \mathrm{E}$ (WGS 84) 25 Jun. 2010 M.K. Curran, G.B. Pearson (PSC0889R) Trog scrape' (WAM E84011); 1 , 'W.A.: Mining Area C, c. 87 km NW. Newman $22^{\circ} 55^{\prime} 33.10^{\prime \prime} \mathrm{S} 119^{\circ} 02^{\prime} 06.70^{\prime \prime} \mathrm{E}$ (WGS 84) 08 Dec. 2007 J.S. Cocking, M.D. Scanion (GA0165R) Trog scrape, 55 m' (CBM); 1 , 'W.A.: Jinidi, c. 65 km NW. Newman 22 ${ }^{\circ} 58^{\prime} 22.80^{\prime \prime S} 119^{\circ} 15^{\prime} 32.40^{\prime \prime} \mathrm{E}$ (WGS 84) 01 Sep. 2011 D.C. Main, J.W. Quartermaine (JIN0109R) Trog scrape, 40 m' (WAM E84008).

\section{DIAGNOSIS}

Yellow, blind, narrow and elongate species with elongate, posteriad little widened, almost elliptical head, narrow and elongate, and dorsally slightly convex elytra; distinguished from $T$. longipenne sp. nov. by slightly shorter, apicad slightly widened elytra, slightly shorter antenna, and longer, wider, rather spoon-shaped, very depressed apex of the aedeagus. 


\section{DESCRIPTION}

Measurements: Length: 4.2-4.3 mm; width: $1.2 \mathrm{~mm}$. Ratio length/width of head: 1.45-1.48; ratio width/length of pronotum: 1.38-1.45; ratio width of widest diameter/ width of base of pronotum: 1.71-1.72; ratio width of head/width of pronotum: 1.06-1.07; ratio length/width of elytra: 2.06-2.07; ratio length/width of scapus: 6.0 ; ratio length/width of $6^{\text {th }}$ antennomere: 4.0 ; ratio length/width of metatibia: 5.2-5.3.

Colour: Upper and lower surfaces, palpi, antenna, and legs pale yellow.

Head (Figure 2): Elongate, slightly wider than pronotum, posteriad little widened, about elliptical, widely rounded towards neck. Upper surface rather convex. Eye absent. Frons with a very short, shallow, impression on either side just behind the clypeal suture. Neck short, extremely narrow, separated by a deep furrow. Clypeus small, apical margin convex, trisetose, i.e. with a slightly shorter seta in middle, lateral setae elongate. Labrum deeply concave at apex, 6-setose, the lateral seta longer than the median ones. Mandibles comparatively elongate, wide, at apex suddenly incurved, lateral margin near base with several elongate setae. Palpi rather narrow and elongate, apical palpomeres slightly widened apicad, palpi densely

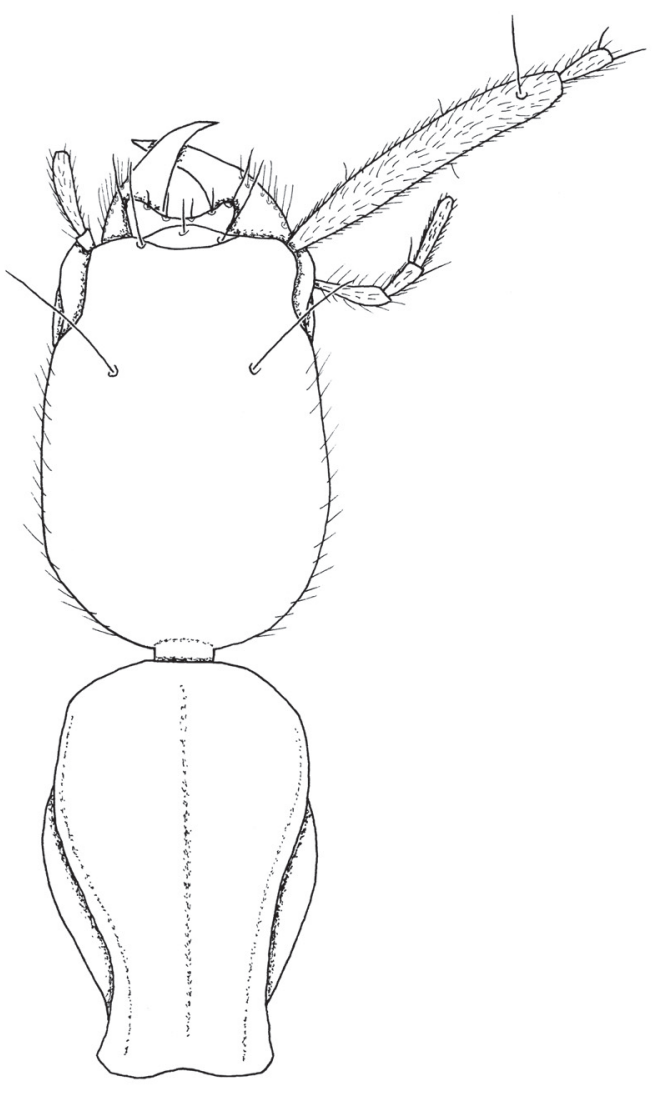

FIGURE 2 Head and pronotum: 1, Typhlozuphium humicolum sp. nov. Scale bars $=1 \mathrm{~mm}$. pilose; the basal palpomere of the maxillary palpus rather hirsute, the basal palpomere of the labial palpus at apex with several elongate setae. Mentum with a quadrate tooth, 4-setose behind the tooth. Labium short, glossa wide at apex, paraglossae apparently fused to glossa, at apex apparently 5-setose. Lacinia elongate, median margin with many elongate, stout setae. Galea narrow and elongate, impilose. Antenna very elongate, scapus longer than diameter of head, with one elongate seta near apex and several very short, erect setae within the fairly dense, depressed pilosity; median antennomeres c. $4 \mathrm{x}$ as long as wide, with very dense, adpressed, very short pilosity. One supraorbital seta present, situated at apical third of head. Surface of head sparsely punctate and pilose, pilosity on surface short and inclined anteriad, laterally longer. Microreticulation fine and superficial, about isodiametric.

Prothorax (Figure 2): Rather narrow and elongate, much longer than wide, cordiform, widest at or slightly in front of middle. Apex rather wide, in middle straight, laterally markedly oblique; apical angles obtusely rounded. Lateral margin in apical half slightly oblique and convex, in basal half concave, near base straight. Basal angles slightly removed from base, very slightly triangularly produced. Base rather narrow, in middle slightly concave. Lateral margin slightly carinate, marginal explanation in apical half narrow, very shallow, in basal half slightly wider and deeper. Both, apex and base not margined. Disk rather depressed but uneven, in apical half slightly convex, in basal half slightly impressed. Median line fine, inconspicuous, slightly impressed, almost attaining apex and base. No transverse sulci visible. Basal grooves shallow, narrow, rather elongate. In middle of pronotum proepisternum well visible from above, wide and convex, producing the widest diameter of pronotum. No marginal setae or punctures visible. Surface with dense, coarse, transverse furrows, interrupted by rather dense punctures, with fairly dense, short, declined pilosity. Microreticulation extremely fine and superficial, composed of more or less isodiametric meshes.

Elytra: Elongate and almost parallel-sided; dorsal surface convex but depressed on disk. Humerus oblique. Lateral margins straight. Apex very oblique, not sinuate, not incurved at suture, narrowly marginate; external apical angles widely rounded. At least two median striae just perceptible though barely impressed, median intervals in basal half very slightly raised. No discal punctures and setae visible. Lateral marginal setae extremely elongate, composed of two groups: 4 setae behind humerus, 2 setae near external apical angle. Surface with dense and rasp-like punctation. Pilosity dense, fairly elongate, declined posteriad. Microreticulation distinct, isodiametric. Surface rather dull. Metathoracic wings completely reduced.

Lower surface: Moderately densely punctate and pilose. Pilosity rather elongate, on head and prothorax inclined anteriad, on abdomen inclined posteriad. Metepisternum short, little longer than wide at apex. 
$1^{\text {st }}$ visible abdominal sternite very elongate, almost as long behind metacoxa as the three following sternites. Terminal sternite in both sexes with one elongate seta on either side.

Legs: Very narrow and elongate, densely pilose. Metacoxa $>5 \mathrm{x}$ as long as wide. Tarsi densely pilose on upper and lower surfaces. $4^{\text {th }}$ tarsomeres widened and deeply cleft, densely pilose on lower surface. Tarsal claws very small. Male protarsus not widened and squamose on lower surface, similar to that of female.

Male genitalia (Figure 5): Genital ring fairly narrow, slightly asymmetric, with wide base and rounded apex. Aedeagus rather elongate, straight, little widened in middle, with slightly convex lower surface. Apex markedly depressed, wide and spoon-shaped, at tip widely rounded. Orificium elongate, situated in middle of upper surface, dorsally on either side with a narrow, elongate rod. Internal sac with some folds and a narrow, curved sclerite at bottom in middle of the left side. Parameres moderately large, very dissimilar, right one very short, both asetose.

Female gonocoxites (Figure 7): Gonocoxite 1 elongate, with c. 6 extremely elongate setae at the upper ventral rim. Gonocoxite 2 falciform, without any setae. Also the lateral plate at its upper median rim with one or two extremely elongate setae.

Variation: Slight variation noted in relative length of prothorax.

\section{REMARKS}

The specimens were sampled by 'trog scrape' as discussed above under 'Collecting method', between $40 \mathrm{~m}$ and $55 \mathrm{~m}$ below the surface.

\section{DISTRIBUTION}

All specimens were collected in an area north-west of Newman, in the Pilbara region of north-western Western Australia.

\section{ETYMOLOGY}

The name refers to the occurrence of this species in the soil.

\section{Typhlozuphium longipenne sp. nov.}

Figures 3, 6

http://www.zoobank.org/urn:Isid:zoobank. org:act:DCC32D29-4318-44C9-80E8-3AD242EF0729

\section{MATERIAL EXAMINED}

\section{Holotype}

Australia: Western Australia: ,WA: Mining Area C c. $95 \mathrm{~km}$ SE Wittenoom 22 54'34.93”S 118 56'34.08"'E (WGS 84) 09 November 2013 S.R. Bennett, J.W. Quartermaine (PSB0107R) Trog scrape, 60 m' (WAM E88465).

\section{DIAGNOSIS}

Yellow, blind. narrow and elongate species with elongate, posteriad little widened, almost elliptical head, narrow and elongate, and dorsally slightly convex elytra; distinguished from T. humicolum sp. nov. by longer and absolutely parallel-sided elytra, slightly longer antenna, and shorter, narrower, about triangular, less depressed apex of the aedeagus.

\section{DESCRIPTION}

Measurements: Length: $4.3 \mathrm{~mm}$; width: $1.15 \mathrm{~mm}$. Ratio length/width of head: 1.51; ratio width/length of pronotum: 1.45; ratio width of widest diameter/width of base of pronotum: 1.78; ratio width of head/width of pronotum: 1.06; ratio length/width of elytra: 2.18 ; ratio length/width of scapus: 6.5 ; ratio length/width of $6^{\text {th }}$ antennomere: 4.4; ratio length/width of metatibia: 5.4.

Colour: Upper and lower surfaces, palpi, antenna, and legs pale yellow.

Head (Figure 3): Elongate, slightly wider than pronotum, posteriad barely widened, about elliptical, widely rounded towards neck. Upper surface rather convex. Eye absent. Frons with a very short, shallow, impression on either side just behind the clypeal suture. Neck short, extremely narrow, separated by a deep furrow. Clypeus small, apical margin convex, trisetose, i.e. with a slightly shorter seta in middle, lateral setae elongate. Labrum deeply concave at apex, 6 -setose, the lateral seta longer than the median ones.

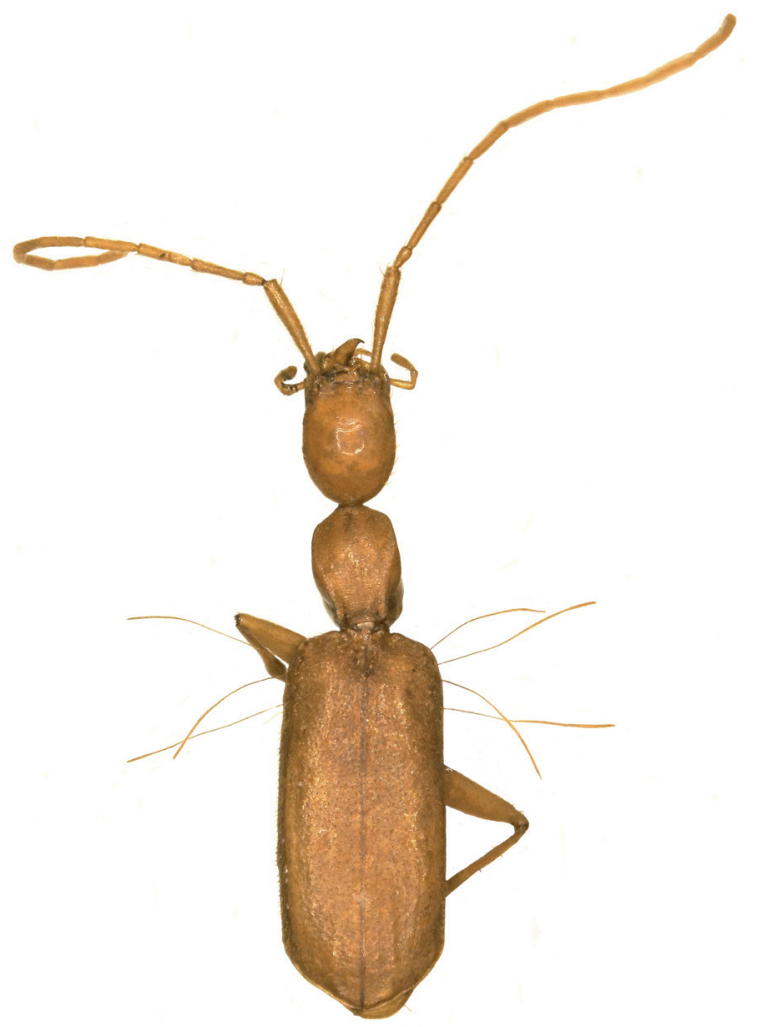

FIGURE 3 Typhlozuphium longipenne sp. nov., habitus. Body length: $4.3 \mathrm{~mm}$. 
Mandibles comparatively elongate, wide, at apex suddenly incurved, lateral margin near base with several elongate setae. Palpi rather narrow and elongate, apical palpomeres slightly widened apicad, palpi densely pilose; the basal palpomere of the maxillary palpus rather hirsute, the basal palpomere of the labial palpus at apex with several elongate setae. Mentum with a quadrate tooth, 4-setose behind the tooth. Labium short, glossa wide at apex, paraglossae apparently fused to glossa, at apex apparently 5-setose. Lacinia elongate, median margin with many elongate, stout setae. Galea narrow and elongate, impilose. Antenna very elongate, scapus longer than diameter of head, with one elongate seta near apex and several very short, erect setae within the fairly dense, depressed pilosity; median antennomeres $>4 \mathrm{x}$ as long as wide, with very dense, adpressed, very short pilosity. One supraorbital seta present, situated at apical third of head. Surface of head sparsely punctate and pilose, pilosity on surface short and inclined anteriad, laterally longer. Microreticulation fine and superficial, about isodiametric.

Prothorax (Figure 3): Rather narrow and elongate, much longer than wide, cordiform, widest slightly in front of middle. Apex rather wide, in middle straight, laterally markedly oblique; apical angles obtusely rounded. Lateral margin in apical half slightly oblique and convex, in basal half concave, near base straight. Basal angles slightly removed from base, very slightly triangularly produced. Base rather narrow, in middle slightly concave. Lateral margin slightly carinate, marginal explanation in apical half narrow, very shallow, in basal half slightly wider and deeper. Both, apex and base not margined. Disk rather depressed but uneven, in apical half slightly convex, in basal half slightly impressed. Median line fine, inconspicuous, slightly impressed, almost attaining apex and base. No transverse sulci visible. Basal grooves shallow, narrow, rather elongate. In middle of pronotum proepisternum well visible from above, wide and convex, producing the widest diameter of pronotum. No marginal setae or punctures visible. Surface with dense, coarse, transverse furrows, interrupted by rather dense punctures, with fairly dense, short, declined pilosity. Microreticulation extremely fine and superficial, composed of more or less isodiametric meshes.

Elytra (Figure 3): Very elongate, parallel-sided; dorsal surface convex but depressed on disk. Humerus oblique. Lateral margins straight. Apex very oblique, not sinuate, not incurved at suture, narrowly marginate; external apical angles widely rounded. Two median striae just perceptible though barely impressed, median intervals in basal half very slightly raised. No discal punctures

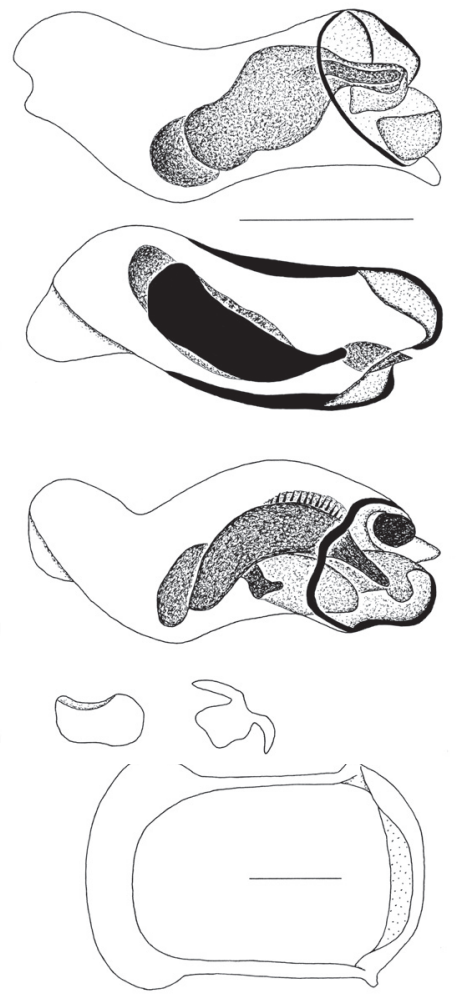

FIGURE 4 Male aedeagus, left side, lower surface, upper surface, parameres, genital ring of Parazuphium pilbarae sp. nov. Scale bars $=0.25 \mathrm{~mm}$.
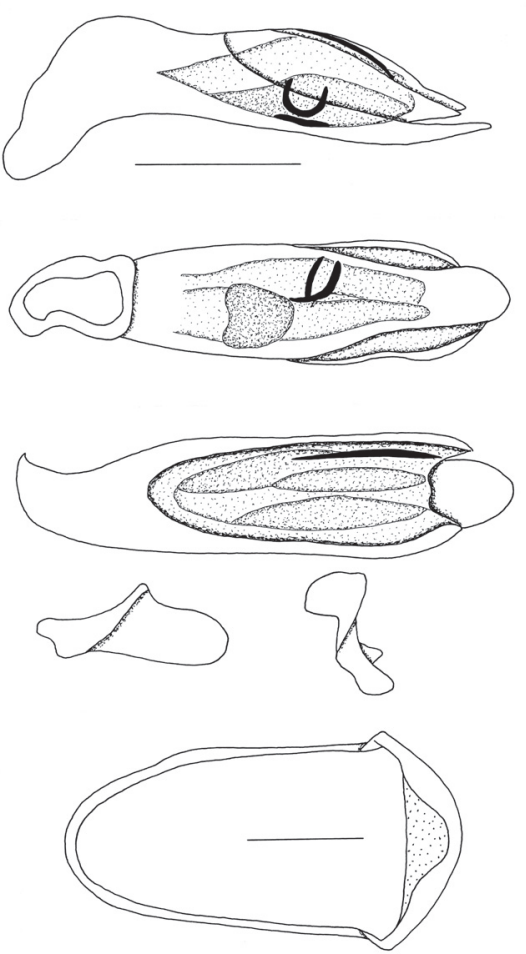

FIGURE 5 Male aedeagus, left side, lower surface, upper surface, parameres, genital ring of Typhlozuphium humicolum sp. nov. Scale bars $=0.25 \mathrm{~mm}$. 

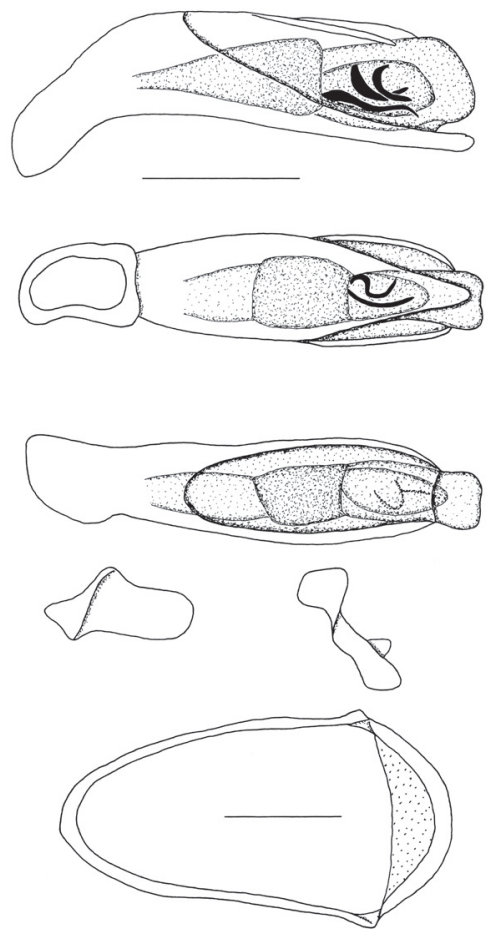

FIGURE 6 Male aedeagus, left side, lower surface, upper surface, parameres, genital ring of Typhlozuphium longipenne sp. nov. Scale bars $=0.25 \mathrm{~mm}$.

and setae visible. Lateral marginal setae extremely elongate, composed of two groups: 4 setae behind humerus, 2 setae near external apical angle. Surface with dense and rasp-like punctation. Pilosity dense, fairly elongate, declined posteriad. Microreticulation distinct, isodiametric. Surface rather dull. Metathoracic wings completely reduced.

Lower surface: Moderately densely punctate and pilose. Pilosity rather elongate, on head and prothorax inclined anteriad, on abdomen inclined posteriad. Metepisternum short, little longer than wide at apex. $1^{\text {st }}$ visible abdominal sternite very elongate, almost as long behind metacoxa as the three following sternites. Terminal sternite in male with one elongate seta on either side.

Legs: Very narrow and elongate, densely pilose. Metacoxa $>5 \mathrm{x}$ as long as wide. Tarsi densely pilose on upper and lower surfaces. $4^{\text {th }}$ tarsomeres widened and deeply cleft, densely pilose on lower surface. Tarsal claws very small. Male protarsus not widened and squamose on lower surface.

Male genitalia (Figure 6): Genital ring fairly narrow, slightly asymmetric, with wide base and rounded apex. Aedeagus rather elongate, straight, little widened in middle, with slightly convex lower surface. Apex moderately depressed, rather narrow, triangular, with obtuse tip. Orificium elongate, situated in middle of

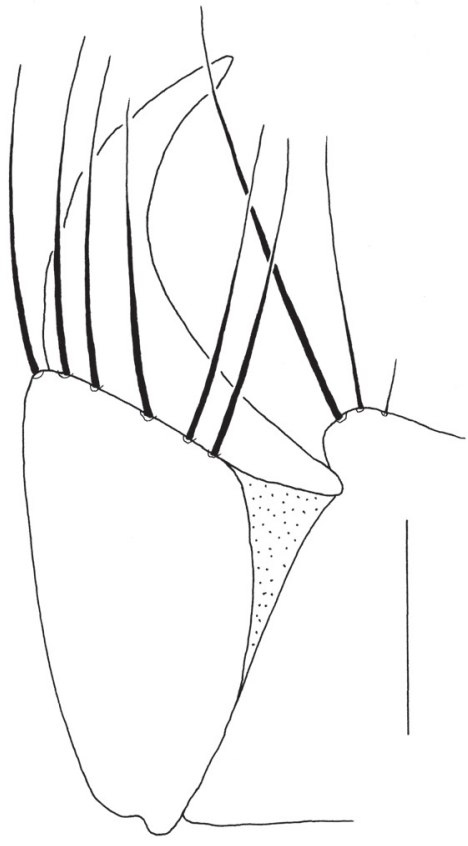

FIGURE 7 Typhlozuphium humicolum sp. nov., female gonocoxites and lateral plate. Scale bar = $0.1 \mathrm{~mm}$.

upper surface, dorsally on either side with a narrow, elongate rod. Internal sac with some folds and two narrow, curved sclerites at bottom in middle. Parameres moderately large, very dissimilar, right one very short, both asetose.

Female gonocoxites: Unknown.

Variation: Unknown.

\section{REMARKS}

The holotype was sampled by 'trog scrape' as discussed above under 'Collecting method', at $60 \mathrm{~m}$ below the surface.

\section{DISTRIBUTION}

This species is known only from the vicinity of Wittenoom, in the Pilbara reigon of north-western Western Australia.

\section{ETYMOLOGY}

The name refers to the very elongate, parallel-sided elytra of this species.

\section{REMARKS}

The new species and new genus described above demonstrate the insufficient knowledge on the Australian Zuphiini. Application of new, elaborate 
collecting methods, as mentioned in above, can in the future bring to light new and interesting soil inhabiting or subterraneous species and might further raise the number of zuphiine species in Australia. This sampling methods should be conducted more systematically and in other parts of Australia. We are however, already much obliged to the collectors for their novel approach which illustrates an excellent example for future collecting.

Both new species of the genus Typhlozuphium are very closely related and differ only slightly in body shape, length of antenna, and in shape and structure of the aedeagus. However, the differences suggest that species of this genus possess quite restricted ranges. This is not too surprising for blind, flightless, and subterranean species. Therefore, we can suppose that additional species might occur in other parts of the Pilbara. Very restricted ranges of most subterranean arthropod species sampled during the Pilbara survey were also suggested by Halse and Pearson (2014) in their report on that survey.

The high grade of similarity in both species of Typhlozuphium suggests a rather recent origin, resp. separation of both species, which still are very closely related. Certainly, it is not yet possible to speculate about the phylogenetic relationships of the Pilbara subterranean zuphiines or about their biogeographic history, but perhaps future surveys might reveal very interesting results for both questions.

Few blind zuphiine species thus far have been recorded from Australia. The two species (and genera) described by Moore (1995) from caves in the Nullarbor Plain are true cave inhabiting species which are even more adapted to subterranean life than Typhlozuphium, have lost even more character states of epigean Zuphiines and have acquired more distinctive attributes. For Speothalpius grayi Moore, therefore, its affiliation to Zuphiini even remains unsettled.

\section{ACKNOWLEDGEMENTS}

I am indebted to Nadine Guthrie, Brian Hanich, and Nikolai Tatarnic for the loan of the specimens, and to Dean Main for additional information about sampling methods.

\section{REFERENCES}

Baehr, M. (1984). Revision der australischen Zuphiinae. 1. Gattung Acrogenys Macleay (Insecta, Coleoptera, Carabidae). Spixiana 7: 115-134.

Baehr, M. (1985a). Revision of the Australian Zuphiinae. 3. The genus Pseudaptinus Castelnau (Insecta, Coleoptera, Carabidae). Spixiana 8: 33-57.

Baehr, M. (1985b). Revision of the Australian Zuphiinae. 4. The genus Parazuphium Jeannel (Insecta, Coleoptera, Carabidae). Spixiana 8: 295-321.

Baehr, M. (1986a). Revision of the Australian Zuphiinae. 5. The genus Zuphium Latreille (Insecta, Coleoptera, Carabidae). Spixiana 9: 1-23.
Baehr, M. (1986b). Revision of the Australian Zuphiinae. 6. The genus Planetes Macleay. Supplement to the other genera (Insecta, Coleoptera, Carabidae). Spixiana 9: 151-168.

Baehr, M. (1988). Revision of the Australian Zuphiinae 2. Colasidia monteithi sp. nov. from North Queensland, first record of the tribe Leleupidiini in Australia (Insecta: Coleoptera: Carabidae). Memoirs of the Queensland Museum 25: 135-140 (1987).

Baehr, M. (1992). A new Acrogenys Macleay from Central Australia. Supplement to the revision of the Australian Zuphiinae (Insecta, Coleoptera, Carabidae). Spixiana 15: $75-80$.

Baehr, M. (1995). A new species of Pseudaptinus Castelnau from Australia. 2nd supplement to the "Revision of the Australian Zuphiinae" (Insecta, Coleoptera, Carabidae, Zuphiinae). Koleopterologische Rundschau 65: 15-18.

Baehr, M. (2001). New species and new records of Zuphiinae from Australia (Coleoptera: Carabidae). Special Bulletin of the Japanese Coleoptological Society 1: 83-101.

Baehr, M. (2008a). Two new species of the genus Pseudaptinus Castelnau from northern Australia (Insecta: Coleoptera: Carabidae: Zuphiini). The Beagle. Records of the Museum and Art Gallery of the Northern Territory 24: 55-62.

Baehr, M. (2008b). New species of the zuphiine genus Acrogenys Macleay from Australia (Insecta, Coleoptera, Carabidae, Zuphiinae). Coleoptera 11 (2007): 113-124.

Baehr, M. (2010). A new species of the genus Zuphium Latreille from northern central Queensland, Australia (Coleoptera, Carabidae, Zuphiinae). Spixiana 33: 65-68.

Baehr, M. (2012). Three new species of the genus Acrogenys Macleay, 1864 from Australia (Insecta, Coleoptera, Carabidae, Zuphiini). Coleoptera 108: 15-24.

Bouchard, P., Bousquet, Y., Davies, A.E., Alonso-Zarazaga, M.A., Lawrence, J.F., Lyal, C.H.C., Newton, A.F., Reid, C.A.M., Schmitt, M., Slipinski, S.A. and Smith, A.B.T. (2011). Family-group names in Coleoptera (Insecta). ZooKeys 88 (Special Issue): 1-971.

Halse, S. A. and Pearson, G.B. (2014). Troglofauna in the vadose zone: comparison of scraping and trapping results and sampling adequacy. Subterranean Biology 13: 17-34.

Habu, A. (1967). Fauna Japonica: Carabidae. Truncatipennes group (Insecta: Coleoptera). Biogeographical Society of Japan, 338 pp.

Jeannel, R. (1942) Coléoptères Carabiques. Deuxième Partie. Faune de France 40: 572-1173.

Lorenz, W. (2005). Systematic list of extant ground beetles of the world (Insecta Coleoptera "Geadephaga": Trachpachidae and Carabidae incl. Paussinae, Cicindelinae. Rhysodidae). 2nd ed. Printed by the author, Tutzing. $530 \mathrm{pp}$.

Moore, B.P. (1995). Two remarkable new genera and species of troglobiotic Carabidae (Coleoptera) from Nullarbor Caves. Journal of the Australian Entomological Society 34: 159-161.

MANUSCRIPT RECEIVED 5 JUNE 2014; ACCEPTED 13 NOVEMBER 2014. 